\title{
Multiple environmental controls explain global patterns in soil animal communities
}

\author{
Alice S. A. Johnston ${ }^{1}$ (D) $\cdot$ Richard M. Sibly ${ }^{1}$
}

Received: 8 August 2019 / Accepted: 30 March 2020 / Published online: 7 April 2020

(c) The Author(s) 2020

\begin{abstract}
Soil animals play important roles in ecosystem functioning and stability, but the environmental controls on their communities are not fully understood. In this study, we compiled a dataset of soil animal communities for which the abundance and body mass of multiple soil animal groups were recorded. The mass-abundance scaling relationships were then used to investigate multiple environmental controls on soil animal community composition. The data reveal latitudinal shifts from high abundances of small soil animals at high latitudes to greater relative abundances of large soil animals at low latitudes. A hierarchical linear mixed effects model was applied to reveal the environmental variables shaping these latitudinal trends. The final hierarchical model identified mean annual temperature, soil $\mathrm{pH}$ and soil organic carbon content as key environmental controls explaining global mass-abundance scaling relationships in soil animal communities $\left(R_{\mathrm{c}}^{2}=0.828, N_{\text {group }}=117\right)$. Such relationships between soil biota with climate and edaphic conditions have been previously identified for soil microbial, but not soil animal, communities at a global scale. More comprehensive global soil community datasets are needed to better understand the generality of these relationships over a broader range of global ecosystems and soil animal groups.
\end{abstract}

Keywords Community composition $\cdot$ Mass-abundance $\cdot$ Size spectra $\cdot$ Soil animals $\cdot$ Soil organic carbon $\cdot$ Soil pH . Temperature

\section{Introduction}

Soil animals play important roles in ecosystem functions such as carbon and nutrient cycling, water regulation and primary production. The composition of soil animal communities thus strongly influences ecosystem multifunctionality (Wagg et al. 2014). For instance, soil animal communities alter microbial activity, litter decomposition, nutrient mineralization and soil respiration rates, and plant community composition (Bradford et al. 2002; De Deyn et al.

Communicated by Stefan Scheu.

Electronic supplementary material The online version of this article (https://doi.org/10.1007/s00442-020-04640-w) contains supplementary material, which is available to authorized users.

Alice S. A. Johnston

alice.johnston@reading.ac.uk

Richard M. Sibly

r.m.sibly@reading.ac.uk

1 School of Biological Sciences, University of Reading, Reading RG6 6AH, UK
2003; Eisenhauer et al. 2012a, b; Johnston and Sibly 2018). Soil animal groups, of different body size ranges, also display divergent responses to global environmental changes (Blankinship et al. 2011; Eisenhauer et al. 2012a, b). Shifts in soil animal community composition could thus have dramatic consequences for terrestrial ecosystem functioning and stability in the future (Sjursen et al. 2005; Suttle et al. 2007; Briones et al. 2009; Eisenhauer et al. 2014; Handa et al. 2014). Yet, little is known about the environmental controls that shape entire soil animal communities at a global scale.

Petersen and Luxton (1982), in the most comprehensive synthesis of soil animal abundances and biomasses to date, revealed non-linear shifts in soil animal community biomass with latitude. Total soil animal biomass declined from temperate ecosystems (forests and grasslands) towards both arctic and tropical ecosystems and were accompanied by shifts in soil animal community composition. For instance, the biomass of smaller soil animal groups (Nematoda, Collembola, Enchytraeidae and Acari) increased in arctic and decreased in tropical, relative to temperate, ecosystems. In a more recent synthesis, Fierer et al. (2009) compiled biomass measurements for 
five soil animal groups (Nematoda, Acari, Collembola, Enchytraeidae and Oligochaeta) from different studies and found similar variations in soil animal community composition across seven biomes. The underlying environmental controls shaping latitudinal shifts in soil animal communities at a global scale, however, have not been identified. Our study aims to address this knowledge gap by synthesising data for entire soil animal communities and the environmental controls that influence their composition across globally distributed sites.

Climatic constraints are classically considered the key drivers of soil animal distribution and abundance (Wardle et al. 2004). For instance, a global litter decomposition study found the influence of soil animals to be climate dependent (Wall et al. 2008). Recent global syntheses of soil animal groups further identify climate as an important driver of nematode (Van Den Hoogen et al. 2019) and earthworm (Johnston 2019; Phillips et al. 2019) community metrics. Yet, inconsistent observations from soil warming experiments suggest that climate effects on soil animals are subsidiary to resource effects at the community and site level (Ernakovich et al. 2014; Thakur et al. 2014; Dorrepaal et al. 2016; Robinson et al. 2018). Resource availability and diversity influence soil animals by altering the amount of energy and nutrients available for consumption (Mueller et al. 2016; Van der Wal et al. 2009), and opportunities for niche differentiation between soil animal groups (Wardle 2006). Soil animals, however, consume diverse resources, including plant roots, leaf litter, microorganisms and one another. Nevertheless, strong coupling relationships exist between plant productivity and soil animal communities (Yang et al. 2018), suggesting shared environmental controls on plant and soil animal communities.

Nutrients play a central role in plant allocation strategies. When nitrogen $(\mathrm{N})$ and/or phosphorous $(\mathrm{P})$ are limiting, photosynthate $\mathrm{C}$ is allocated preferentially belowground to root growth to compete for limited nutrients, and otherwise allocated aboveground to shoot and leaf growth to compete for limiting light (Gill and Finzi 2016). Plant allocation aboveor belowground has consequences for soil communities, by directing the availability of food resources to different soil animal groups. A regional study of the body-size spectra of soil bacteria, fungi and micro- (Nematoda) and meso-fauna (Acari, Collembola, Enchytraeidae) in 22 Dutch grasslands, for instance, found greater $\mathrm{N}$ and $\mathrm{P}$ availability to support higher abundances of the larger soil animals sampled in the study (Mulder and Elser 2009). These observations suggest that greater aboveground plant production, related to higher soil nutrient contents, will support the presence, and greater abundances of larger soil animal groups (macrofauna, e.g. Chilopoda, Clitellata) at a global scale. Conversely, we would expect nutrient limited soils, where plant production is directed mainly belowground, to harbour greater abundances of smaller soil animal groups (e.g., micro- and meso-fauna).

Global patterns in soil microbial communities have received much more attention than soil animals, and evidence suggests that the relative abundance and biodiversity of bacteria and fungi groups are strongly influenced by both climate and soil nutrients (Treseder 2008; Serna-Chavez et al. 2013; Koyama et al. 2014; Tedersoo et al. 2014; Delgado-Baquerizo et al. 2017). Given the global relationships between climate and plant nutrient stoichiometry with litter decomposition rates (Parton et al. 2007) and the influence of soil animals on decomposition (García-Palacios et al. 2013), we hypothesise that these environmental controls (climate and nutrients) extend to soil animal communities. To test this hypothesis, we conducted a comparative analysis of global soil animal communities. First, we compiled a dataset of soil animal communities for which abundance and biomass were recorded for multiple soil animal groups across globally distributed sites. We then characterised soil community composition by mass-abundance scaling relationships to investigate global shifts in soil animal body-size spectra. Finally, a hierarchical linear mixed effect model was used to test the importance of multiple environmental controls on global soil animal communities.

\section{Materials and methods}

\section{Synthesis of soil animal community data}

Soil animal community studies were synthesised from the literature using Web of Science (www.webofknowledge. com). To be included in the dataset, studies had to report field-collected abundances and biomass or body masses for at least four soil animal groups (to be representative of the soil animal community) in un-manipulated field conditions. Search terms included soil or belowground, animal, fauna, biota, decomposer, invertebrate or detrivore, community, and excluded the terms laboratory, microcosm or mesocosm in the title. Additional search terms for the topic included: population or community; abundance, density, number or biomass; and field, forest, grassland, or natural. Field studies were further excluded if they did not report site information such as latitude, longitude or site location, or the year for the extraction of climatic data. Most studies evaluated, in total 54, did not include both abundance and biomass endpoints or only studied a few soil animal groups.

Twelve studies met the search criteria, reporting thirteen soil animal communities in ecosystems ranging from arctic tundra to tropical rainforest (Table 1). Soil animal groups include Nematoda, Collembola, Enchytraeidae, Acari, Diptera, Hymenoptera, Coleoptera, Isopoda, Chilopoda, Araneae, Blattodea, Diplopoda, Gastropoda, Clitellata 
Table 1 Summary of the soil animal community studies included in the dataset

\begin{tabular}{|c|c|c|c|}
\hline Study & Location & Vegetation & Soil type \\
\hline Anderson et al. (1983) & $\begin{array}{l}\text { Sarawak, Malaysia } \\
4.37^{\circ} \mathrm{N}, 113.97^{\circ} \mathrm{E}\end{array}$ & Dipterocarp rainforest & $\begin{array}{l}\text { Well-drained organic soil } \\
\text { over limestone }\end{array}$ \\
\hline Axelsson et al. (1984) & $\begin{array}{l}\text { Andersby, Sweden } \\
60.15^{\circ} \mathrm{N}, 17.83^{\circ} \mathrm{E}\end{array}$ & Oak-hazel woodland & Glacial boulder till \\
\hline Byzova, Uvarov and Petrova (1995) & $\begin{array}{l}\text { Spitsbergen, Svalbard } \\
77.00^{\circ} \mathrm{N}, 15.55^{\circ} \mathrm{E}\end{array}$ & Arctic tundra (Salix polaris) & Gelic Gleysol \\
\hline \multirow[t]{2}{*}{ Coulson and Whittaker (1978) } & $\begin{array}{l}\text { Cumbria, England } \\
54.65^{\circ} \mathrm{N}, 2.45^{\circ} \mathrm{W}\end{array}$ & $\begin{array}{l}\text { aLimestone (Festuca-Agrostis) } \\
\text { grassland }\end{array}$ & Red-brown limestone soil \\
\hline & & $\begin{array}{l}\text { bAcid (Juncus squarrosus) moor- } \\
\text { land }\end{array}$ & Redistributed peat \\
\hline Dial et al. (2006) & $\begin{array}{l}\text { Sabah, Malaysia } \\
4.00^{\circ} \mathrm{N}, 117.00^{\circ} \mathrm{E}\end{array}$ & Dipterocarp rainforest & Orthic acrisol \\
\hline Hoste-Danyłow et al. (2013) & $\begin{array}{l}\text { Kampinos National Park, Poland } \\
52.35^{\circ} \mathrm{N}, 20.55^{\circ} \mathrm{E}\end{array}$ & Deciduous (Quercus robur) forest & $\begin{array}{l}\text { Glaciofluvial and fluvial } \\
\text { sands }\end{array}$ \\
\hline Huhta and Koskenniemi (1975) & $\begin{array}{l}\text { Hameenlinna, Finland } \\
62.67^{\circ} \mathrm{N}, 26.00^{\circ} \mathrm{E}\end{array}$ & Myrtillus-type spruce forest & Moraine with podzol \\
\hline Moulder and Reichle (1972) & $\begin{array}{l}\text { Tennessee, USA } \\
35.93^{\circ} \mathrm{N}, 84.31^{\circ} \mathrm{W}\end{array}$ & Poplar (Liriodendron) forest & $\begin{array}{l}\text { Colluvial deposits over } \\
\text { limestone }\end{array}$ \\
\hline Rosswall, Persson and Lohm (1977) & $\begin{array}{l}\text { Uppsala, Sweden } \\
60.00^{\circ} \mathrm{N}, 17.19^{\circ} \mathrm{E}\end{array}$ & Abandoned field & Fen peat soil \\
\hline Persson et al. (1980) & $\begin{array}{l}\text { Ivantjarnsheden, Sweden } \\
60.46^{\circ} \mathrm{N}, 16.39^{\circ} \mathrm{E}\end{array}$ & Scots pine (Pinus sylvestris) forest & Iron podzol \\
\hline Richardson et al. (2005) & $\begin{array}{l}\text { El Verde, Puerto Rico } \\
18.32^{\circ} \mathrm{N}, 65.82^{\circ} \mathrm{W}\end{array}$ & $\begin{array}{l}\text { Neotropical (Cyrilla racemiflora) } \\
\text { forest }\end{array}$ & Clay loam \\
\hline Xu et al. (2017) & $\begin{array}{l}\text { Dongling Mountain, China } \\
40.00^{\circ} \mathrm{N}, 115.00^{\circ} \mathrm{E}\end{array}$ & Mixed (Q. liaotungensis) forest & Brown soil \\
\hline
\end{tabular}

and Other Insecta groups (Table 2). Detail at the species level was avoided so that macroecological patterns in soil animal community composition could be evaluated. The raw soil community dataset $\left(N_{\text {raw }}=1503\right)$, which in some cases reported seasonal or annual soil community dynamics (abundance and biomass), were summed across families

Table 2 Summary of the mean body mass and abundance (with \pm standard errors) for each soil animal group in the study, indicating each groups representation in the summarised $\left(N_{\text {group }}\right)$ and raw $\left(N_{\text {raw }}\right)$ dataset, and the lower taxonomic groups included (where applicable)

\begin{tabular}{lcccrl}
\hline Soil animal group & Body mass $(\mathrm{mg} \mathrm{dw})$ & Abundance $\left(\mathrm{ind} \mathrm{m}^{-2}\right)$ & $N_{\text {group }}$ & $N_{\text {raw }}$ & Lower taxanomic groups included \\
\hline Acari & $0.0073 \pm 0.0015$ & $134,977 \pm 72,416$ & 9 & 230 & Gamasina, Oribatida, Mesostigmata \\
Araneae & $1.10 \pm 0.61$ & $3032 \pm 2858$ & 10 & 157 & Linyphiidae, Lycosidae, Gnaphosidae, Clubionidae \\
Blattodea & $3.60 \pm 1.69$ & $253.12 \pm 233$ & 4 & 24 & Isoptera \\
Chilopoda & $4.82 \pm 2.91$ & $188.10 \pm 125$ & 8 & 32 & Geophilomorpha, Lithobiomorpha \\
Coleoptera & $13.95 \pm 10.22$ & $289.12 \pm 98.19$ & 11 & 312 & Staphylinidae, Scydmaenidae, Carabidae \\
Collembola & $0.0335 \pm 0.0234$ & $37,336 \pm 9979$ & 12 & 221 & Tullbergiidae, Isotomidae, Entomobryomorpha, \\
& & & & & Symphypleona, Onychiuridae \\
Diplopoda & $17.99 \pm 5.30$ & $52.26 \pm 30.50$ & 8 & 30 & Julida, Polydesmida \\
Diptera & $6.16 \pm 4.20$ & $1632.33 \pm 770.81$ & 8 & 179 & \\
Enchytraeidae & $0.0720 \pm 0.0264$ & $48,972 \pm 27,351$ & 7 & 20 & \\
Gastropoda & $30.94 \pm 10.82$ & $10.33 \pm 2.96$ & 5 & 17 & Pulmonata \\
Hymenoptera & $0.6928 \pm 0.2059$ & $559.55 \pm 324.96$ & 7 & 46 & Formicidae \\
Isopoda & $5.87 \pm 4.82$ & $81.98 \pm 56.28$ & 5 & 8 & Porcellionidae \\
Nematoda & $0.0001 \pm 0.0001$ & $3,369,911 \pm 769,473$ & 5 & 21 & Adenophorea, Secernentea \\
Clitellata & $35.53 \pm 8.32$ & $220.32 \pm 96.02$ & 7 & 77 & Oligochaeta, Lumbricina, Moniligastrida, Hirudinea \\
Other Insecta & $10.47 \pm 6.01$ & $241.81 \pm 136.76$ & 11 & 129 & Hemiptera, Orthoptera, Staphylinidae, Dermaptera, \\
& & & & Diplura, Thysanoptera
\end{tabular}


and/or species of the same soil animal group and/or averaged across study year/s. The summarised dataset provides 117 data points, relating the abundance and body mass of each sampled soil animal group per study.

Abundances were typically reported as individuals $\mathrm{m}^{-2}$, and biomasses as $\mathrm{mg}$ or $\mathrm{g}$ dry weight $\mathrm{m}^{-2}$. Two studies (Huhta and Koskenniemi 1975; Anderson et al. 1983) reported biomasses as fresh weight, and here generic conversion ratios for 11 soil animal groups were compiled from the literature. Dry mass contents were taken as $0.27,0.43,0.43$, and 0.45 for Araneae, Hymenoptera, Coleoptera, and 'other insect' groups, respectively (Sage 1982); 0.40, 0.35, 0.18, and 0.18 for Acari, Collembola, Enchytraeidae and Clitellata (Törmälä1979); 0.18 for Gastropoda (Lyth 1982) and 0.31 for Chilopoda and Diplopoda (Hadley 1982), and 0.27 for Blattodea (Redford and Dorea 1984).

\section{Environmental variables}

Environmental variables for the thirteen sites sampled in the soil fauna community dataset were compiled, if available, from the respective studies. However, the majority of studies did not report the full scope of environmental variables included in the dataset (latitude, mean annual temperature (MAT), mean annual precipitation (MAP), soil moisture, $\mathrm{pH}$, soil organic carbon, total soil $\mathrm{N}$, total soil $\mathrm{P}$, soil C:N, soil N:P, soil C:P and litter layer). These data gaps were addressed by searching the literature for other measurements made at the same sample sites (for details, see Table S1 in the Supporting Information). Preference was given to data that were reported within 5 years of the study dates, but in some cases, the time gap had to be extended. When soil properties were reported according to soil layer, an average value for all soil layers was calculated. Although data borrowing in this way will introduce error, it was deemed the most appropriate way to fill data gaps in soil properties as global mapping tools such as the ISRIC SoilGrids database do not offer a fine resolution. MAT and MAP, if not reported, were compiled from local NOAA weather stations (www.ncdc.noaa.gov/cdo-web/datatools/findstation) or UK Met Office stations (www.metoffice.gov.uk/public/ weather/climate-historic/) using reported latitude, longitude and study year/s.

\section{Statistical analyses}

Scaling relationships between soil animal body masses $(M$, $\mathrm{mg} \mathrm{dw})$ and abundances $\left(A\right.$, ind $\left.\mathrm{m}^{-2}\right)$ were used to characterise the body-size spectra of soil animal communities. Mass-abundance relationships were first analysed according to a linear model, without interaction terms or random effects. Then interactions between $M$ and climate (arctic, boreal, temperate, tropical), ecosystem type (forest or grassland), study/site (thirteen groups) and latitude $\left({ }^{\circ} \mathrm{N}\right)$ were tested to uncover general patterns in global soil animal communities.

Hierarchical models were then used to test the importance of environmental controls on soil animal community composition across globally distributed sites. In this way, our analysis aimed to uncover the environmental variables structuring soil communities at a global scale. All models were linear mixed effects models, with random effects assigned to the study $\left(N_{\text {study }}=13\right)$, and the soil animal group sample size which varied both across studies and soil fauna groups (mean sample size: $12.85 \pm 2.94, N_{\text {groups }}=117$ ). All statistical analyses were performed in $\mathrm{R}$ version 3.5.1 ( $\mathrm{R}$ Core Team 2018), using the lme4 package and lmer function for linear mixed effects models.

The hierarchy of terms tested followed an order similar to that suggested by de Vries et al. (2012), in which 'controls' are added before 'function'. That is, variables that cause variations in multiple soil properties and plant production (e.g., climate) are added first, so that if 'controls' explain the variation in 'functions' then addition of these variables do not improve model likelihood. Terms were added in the order: climate (MAT and MAP), soil type ( $\mathrm{pH}$, soil moisture and SOC), soil nutrients (total N, total P, C:N, N:P, C:P) and plant litter quantity (litter layer, $\mathrm{g} \mathrm{m}^{-2}$ ). Each variable was added as a linear or quadratic term, with and without interactions with individual body mass $(M)$. Models were then compared by testing their influence on goodness of fit (Akaike's Information Criterion, AIC), model likelihood (Chi-square $p<0.05)$ and parsimony $(\triangle \mathrm{AIC}>2$ for additional degrees of freedom). Models that met these criteria were tested with the subsequent environmental variables. Pseudo-marginal (fixed effect) and conditional (fixed and random effect) $R^{2}$ values for the hierarchical models were calculated using the MuMIn package.

\section{Results}

\section{Soil animal community composition}

Mass-abundance relationships did not differ across thirteen globally distributed sites (Fig. 1). That is, little support was available for interactions between soil animal body mass and climate (arctic, boreal, temperate or tropical), ecosystem type (forest or grassland) or study site $\left(N_{\text {study }}=13\right)$ (Table S2).

Soil animal community body-size spectra were, however, affected by latitude (Table S2) suggesting the influence of environmental controls that co-vary with distance from the equator. We illustrate the influence of latitude on total soil animal abundance and mean soil animal body mass in Fig. 2a and b, respectively. Figure 2 reveals latitudinal shifts 


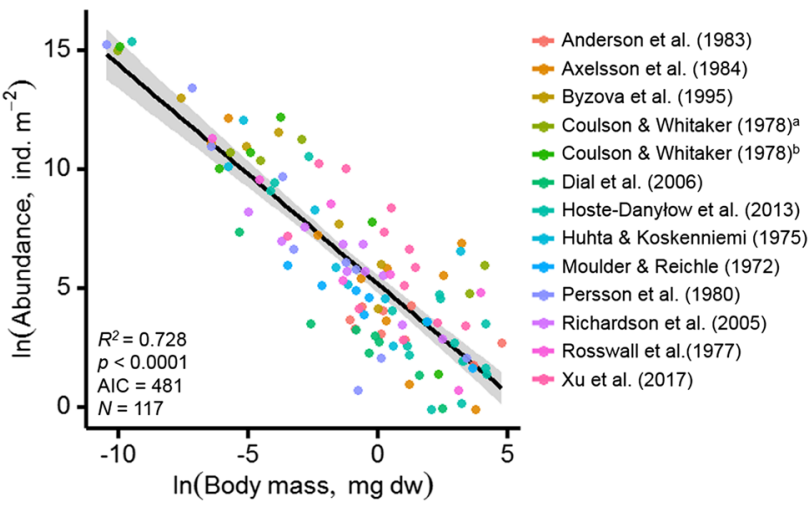

Fig. 1 Mass-abundance scaling relationship across thirteen globally distributed soil animal communities (coloured symbols). Abundance (individuals $\mathrm{m}^{-2}$ ) is plotted against body mass ( $\mathrm{mg}$ dry mass) for the soil animal groups reported $(N=117)$. The best-fitting regression model (black line, with shaded areas showing standard error) was $y=5.23-0.92 x($ Table S2)

in the overall body-size spectra of soil animal communities across thirteen globally distributed sites. Specifically, the data reveal that larger soil animal groups (e.g., Coleoptera,
Chilopoda, Araneae, Clitellata) become increasingly abundant in low latitude (tropical and some temperate) soils, while high latitude (tundra, boreal and some temperate) soils are dominated by smaller animals (e.g., Nematoda, Collembola, Acari, Enchytraeidae).

\section{Multiple environmental controls on global soil animal communities}

A hierarchical linear mixed effect model was used to test the importance of environmental controls (MAT, MAP, soil moisture, SOC, $\mathrm{pH}$, total $\mathrm{N}$, total $\mathrm{P}, \mathrm{C}: \mathrm{N}, \mathrm{N}: \mathrm{P}, \mathrm{C}: \mathrm{P}$ and litter layer) on mass-abundance relationships for each soil animal group $\left(N_{\text {group }}=117\right)$. Addition of three terms improved the hierarchical model fits in comparison to the null model (Table 3), with the condition that adding an additional term must be met with a goodness of fit of $\triangle \mathrm{AIC}>2$ and Chi-square $p<0.05$. Mean annual temperature (MAT), soil $\mathrm{pH}$ and soil organic carbon (SOC) content met these conditions (Table 3 ). The final model had an improved goodness of fit to the data and model likelihood compared to the null model $(\Delta \mathrm{AIC}=16.29$,

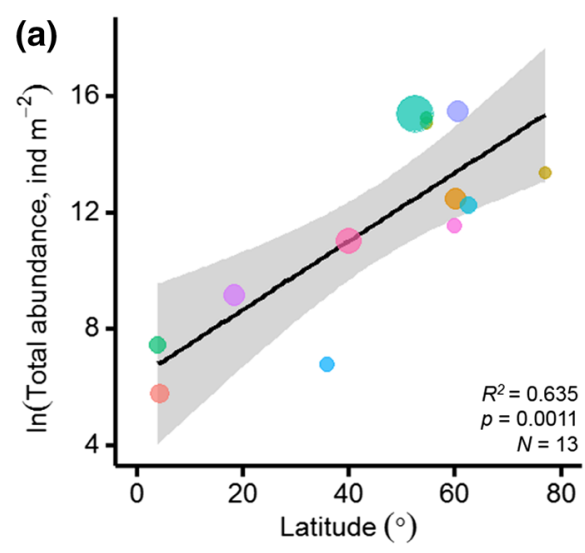

Fig. 2 Latitudinal shifts in soil animal community composition, showing a the relationship between total soil animal community abundance and b mean soil animal body mass across the studies $\left(N_{\text {study }}=13\right)$ with latitude. The best-fitting regression mod-

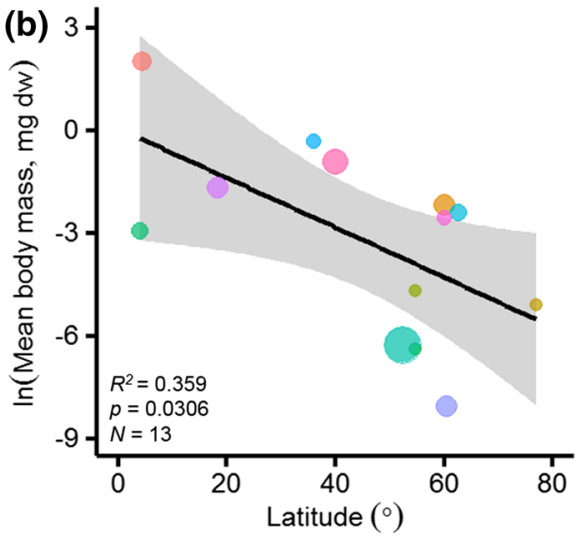

els (black lines, with shaded areas showing standard error) were a $y=6.34+0.12 x$, and $\mathbf{b} y=0.07-\mathrm{v} 0.07 x$. Symbol colours represent the thirteen studies as in Fig. 1, while symbol diameter represents the number of soil animal groups measured in each study

Table 3 Comparison of hierarchical linear mixed effects models used to explain global patterns in soil animal community mass-abundance relationships

\begin{tabular}{|c|c|c|c|c|c|c|c|}
\hline \multicolumn{2}{|c|}{ Environmental controls } & \multirow{2}{*}{$\frac{d f}{4}$} & \multirow{2}{*}{$\frac{R_{\mathrm{m}}^{2}}{0.702}$} & \multirow{2}{*}{$\frac{R_{\mathrm{c}}^{2}}{0.799}$} & \multirow{2}{*}{$\begin{array}{l}\text { Chi-square } p \\
\text { na }\end{array}$} & \multirow{2}{*}{$\frac{\mathrm{AIC}}{481.02}$} & \multirow{2}{*}{$\frac{\Delta \mathrm{AIC}}{16.29}$} \\
\hline Null & $\ln (A) \sim \ln (M)+(1$ Study $)+(1$ Sample size $)$ & & & & & & \\
\hline Climate & $\ln (A) \sim \ln (M) \times$ MAT $+(1$ IStudy $)+(1 \mid$ Sample size $)$ & 6 & 0.759 & 0.823 & 0.003 & 473.41 & 8.68 \\
\hline Edaphic & $\begin{array}{l}\ln (A) \sim \ln (M) \times \mathrm{MAT} \times \mathrm{pH}+\mathrm{pH}^{2} \times \mathrm{SOC}+(1 \mid \text { Study })+(1 \mid \mathrm{Sam}- \\
\text { ple size })\end{array}$ & 14 & 0.805 & 0.828 & 0.002 & 464.73 & 0 \\
\hline
\end{tabular}

The null model does not include interactions between soil animal body mass $(M)$ and environmental variables, while the following models indicate additional terms added to a hierarchical model. Chi-square $p$ value $<0.05$ indicates increased model likelihood following the addition of each term. Overall goodness of fit is determined by AIC values, where lower AICs indicate a better fit to the data $(N=117)$. $\triangle$ AIC's present the difference in AIC values between the different models and the final hierarchical model (Table S3) 
Chi-square $p<0.0001)$. The hierarchical model also showed an improved goodness of fit and model likelihood in comparison to the latitude model $(\triangle \mathrm{AIC}=7.98$, Chisquare $p=0.0026$, Table S2). Importantly, the hierarchical model further reveals the interactions between environmental variables underpinning latitudinal shifts in global soil communities.

Predicted soil animal group abundances from fixed effects ( $M$, MAT, soil $\mathrm{pH}$ and SOC) in the final hierarchical model are compared to observed abundances in Fig. 3a. The distribution of the final hierarchical model residuals, against latitude as an independent variable, further demonstrate deviations between model predictions and observed abundances in Fig. 3b. The largest deviations between predicted and observed abundances occurred in high-latitude boreal or arctic soils, and particularly not only for larger soil animal groups (Chilopoda, Diplopoda, Isopoda, Clitellata) but also for Enchytraeidae. Smallest deviations of the final hierarchical model were present for smaller soil animal groups in high-latitude soils, and larger soil animal groups in temperate and tropical soils. The lowess fit in Fig. 3b, however, indicates prediction of average abundances across latitudes, with average soil animal abundance slightly under-predicted (positive residuals) and over-predicted (negative residuals) at mid-latitude and high-latitude sites, respectively.

The influence of MAT, soil $\mathrm{pH}$ and SOC on soil animal abundances is illustrated in Fig. 4, to provide an assessment of the directionality of relationships between soil animal communities and environmental controls. Results reveal linear declines in abundance with increasing MAT and soil $\mathrm{pH}$ (Fig. 4a, b), and an increase in abundance with increasing SOC (Fig. 4c). At low-latitude sites, higher temperatures, less acidic soils with lower SOC contents supported higher abundances of larger soil animals, whereas high-latitude sites with greater abundances of small soil animals were characterised by low temperatures, acidic soils with higher SOC contents. MAT and soil $\mathrm{pH}$ show strong correlations with latitude across the thirteen sites, whereas SOC contents were most strongly correlated with total soil N, C:P and N:P ratios (Figure S1).

\section{Discussion}

Our study reveals how the body-size spectra of soil animal communities converge across globally distributed sites (Fig. 1 and Table S2). Latitude showed a stronger relationship with soil animal mass-abundance relationships than climate, ecosystem type, or study, revealing shifts from dominance by small soil animals at high latitudes to greater relative abundances of large soil animals at low latitudes (Fig. 2). We used a hierarchical linear mixed effects model to test the importance of multiple environmental controls in shaping these latitudinal trends in global soil animal communities. Climate and edaphic conditions best explained global variations in soil animal community composition (Table 3), with the largest deviations between predicted and observed abundances occurring in high-latitude soils (Fig. 3). The influence of the fixed effects in the final hierarchical model on soil animal abundances was illustrated to show the directionality and strength of each relationship (Fig. 4). Overall, soil animal abundances declined with increasing MAT and soil $\mathrm{pH}$ and increased with SOC contents.

Recent global syntheses of soil communities have identified contrasting environmental controls on the distribution and abundance of soil animal groups of different body size ranges. Nematode abundances, for instance, increase with an increase in SOC content and decline with increasing soil pH at a global scale (Van Den Hoogen et al. 2019). Global earthworm communities, on the other hand, have been more strongly linked to climatic variables (Phillips et al. 2019). Soil acidity also influences global earthworm communities across natural and managed ecosystems, with higher species richness at intermediate soil $\mathrm{pH}$ values (Johnston 2019). Relationships between smaller and larger soil animal groups at a global scale broadly follow those identified for soil fungi
Fig. 3 Final hierarchical model $(\ln (A) \sim \ln (M) \times \mathrm{MAT} \times \mathrm{pH}+\mathrm{pH}$ ${ }^{2} \times$ SOC $+(1$ Study $)+(1 \mid$ Sample size)) a predictions compared to observed soil animal abundances $\left(N_{\text {group }}=117\right)$ across thirteen globally distributed sites, and $\mathbf{b}$ model residuals against latitude, with the lowess fit (black lines, with shaded areas showing standard error) displaying deviations between model predictions and observed abundances

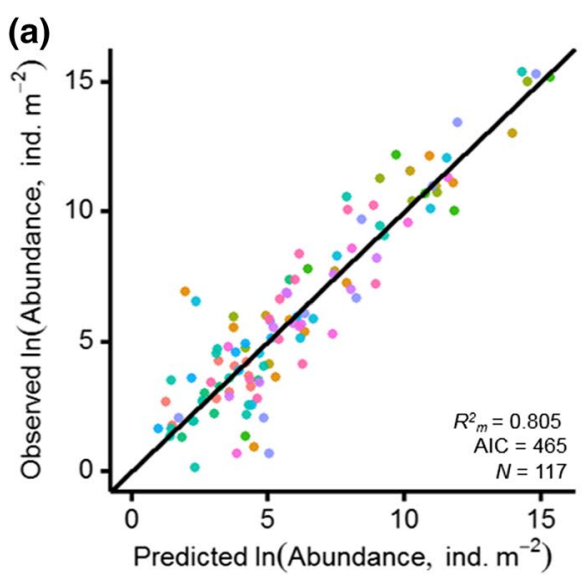

(b)

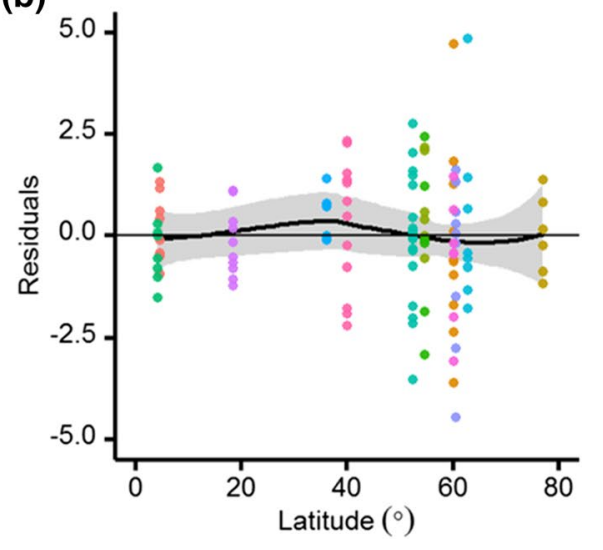



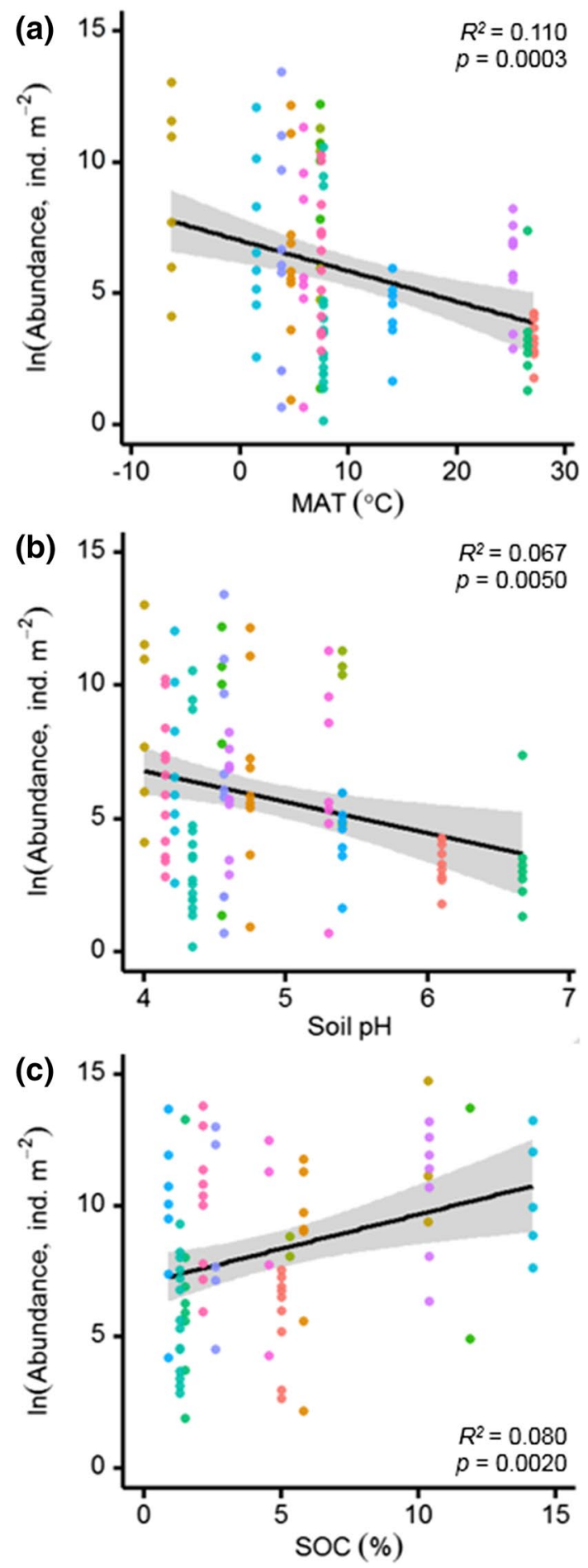

Fig. 4 Relationships between soil animal abundances with a mean annual temperature (MAT, $\left.{ }^{\circ} \mathrm{C}\right)$, b soil $\mathrm{pH}$ and $\mathbf{c}$ soil organic carbon (SOC, \%) content $\left(N_{\text {group }}=117\right.$, symbol colours represent different studies as in Fig. 1). Best-fitting regression models (black lines, with shaded areas showing standard error) were $\mathbf{a} y=14.38-0.29 x$; $\mathbf{b}$ $y=7.34-0.13 x ; \mathbf{c} y=12.16-1.28 x$ and $\mathbf{d} y=4.66+0.25 x$ and bacteria, respectively. Soil bacterial communities, for example, display greater diversity at intermediate $\mathrm{pH}$ values (Fierer and Jackson 2006) while fungi often dominate microbial communities in acidic soils (Rousk et al. 2010; Tedersoo et al. 2014). Declines in soil acidity are further expected to cause microbial community composition shifts from fungal to bacterial dominance, leading to greater trophic transfer efficiency to their soil animal consumers (Carrillo et al. 2016). Our study generalises these results to entire soil animal communities, whereby the dominance of small soil animals (e.g., Nematoda, Acari, Collembola) occurs in high-latitude acidic soils with higher SOC contents, and greater abundances of larger soil animals (e.g., Chilopoda, Coleoptera, Clitellata) occur at mid- to low latitudes in more neutral soils with lower SOC contents.

The influence of climate, and specifically MAT, on soil animal community composition can be understood through the temperature and size dependence of multiple biological processes (Dell et al. 2011). Soil animals are known to display varying temperature sensitivities, with smaller soil animals displaying a greater increase in metabolic rate with increasing temperature (Johnston and Sibly 2018). Smaller animals thus require a greater relative increase in energy from food resources to meet higher metabolic demands with increasing temperature, and so we would expect their populations to become less abundant in warmer climates. In this study we find that smaller soil animal abundances declined in warmer low-latitude climates, while larger soil animals were absent, or present at low abundances, in colder high-latitude climates (Fig. 2). These latitudinal shifts in the body-size spectra of soil animal communities suggest the importance of both soil animal temperature sensitivities and resource availability in shaping their global distributions and abundances. Indeed, soil warming experiments have demonstrated direct impacts of increasing temperature on soil animal communities within biomes (Briones et al. 2009; Bokhorst et al. 2012), but highly variable responses are thought to be driven by the availability of different food resources in mid- and high-latitude soils (Aerts 2006; Robinson et al. 2018).

We hypothesised that soil nutrients would best describe soil animal body-size spectra, due to the strong relationships between nutrient limitation and plant production above- and belowground. Nutrient availability or stoichiometry was not identified as fixed effects in the hierarchical model. However, soil acidity (or $\mathrm{pH}$ ) strongly influences the availability of multiple soil nutrients (Binkley and Vitousek 1989). Across the sites analysed here, for instance, soil $\mathrm{pH}$ was correlated with SOC, total N and P, soil C:N and C:P ratios while SOC was correlated with soil $\mathrm{pH}$, soil $\mathrm{C}: \mathrm{P}$ and $\mathrm{N}: \mathrm{P}$ (Figure S1). Soil acidity has been identified as a key factor influencing soil animal communities at large scales (Mulder and Elser 2009; Johnston 2019), with soil macrofauna (e.g., 
Oligochaeta) largely restricted to soils with $\mathrm{pH}$ values above 3.5 (Schlaghamerský et al. 2014). A lack of clear relationships between soil nutrients ( $\mathrm{N}$ and $\mathrm{P}$ ) and soil animal communities, both here and in other studies, could indicate the overlooked importance of additional soil nutrients which correlate with soil $\mathrm{pH}$. In temperate forests, for instance, litter calcium concentrations among 14 tree species resulted in large changes in soil acidity and earthworm abundance and diversity, 30 years after establishment (Reich et al. 2005). Soil $\mathrm{pH}$, therefore, likely reflects the availability of multiple nutrients, the optimal ranges for which will differ across soil animal groups.

Evidence supporting the influence of temperature, soil $\mathrm{pH}$ and SOC on soil animal communities is available from global decomposition studies. Globally, climate and litter quality (C:N ratios, which correlate with soil $\mathrm{pH}$ and $\mathrm{SOC}$ ) are primary drivers of litter decomposition rates (Parton et al. 2007), while soil animals display variable positive effects on decomposition rates across biomes (Wall et al. 2008). Soil animals have a greater positive effect on litter decomposition rates in warm and wet, compared to cold and dry, ecosystems (García-Palacios et al. 2013). These observations have been explained in terms of low temperature and moisture constraints on biological activity. Our study suggests that temperature, soil $\mathrm{pH}$ and SOC controls on soil animal body-size spectra may play an important role in global patterns of litter decomposition rates because larger soil animals become more abundant where the effect of soil animals on decomposition rates is greatest (e.g., temperate and tropical soils). Greater litter decomposition rates then feedback to plant communities by enhancing nutrient availability for plant uptake (Swift et al. 1998). On the other hand, smaller soil animals show preference for acidic nutrient-limited soils, while reduced litter decomposition by small soil animals at low temperatures leads to soil organic matter accumulation and slow nutrient turnover rates which restrain plant productivity (Petersen and Luxton 1982; Loranger et al. 2001).

Unravelling the ecological mechanisms that underpin soil communities requires comprehensive datasets at multiple levels of biological organisation and ecological scales. The data compiled in this study were purposefully limited to include only studies that report entire soil animal communities, rather than compiling soil animal group data from various locations and sources as in previous syntheses (Petersen and Luxton 1982; Fierer et al. 2009). However, limitations of the dataset constrain robust analysis of global patterns. For instance, there is a general deficit of soil animal studies in mediterranean, subtropical and tropical regions, particularly in comparison to temperate ecosystems. Smaller soil animal groups also tend to be less well studied in warmer climates. Cross-biome studies of seasonal soil microbial and animal community dynamics together with plant and environmental variables are needed to fill these key knowledge gaps. Although such studies are time consuming, new information is crucial for improving our quantitative understanding on the environmental controls shaping soil communities at the globe scale.

In summary, our study reveals the importance of temperature, soil $\mathrm{pH}$ and SOC as key drivers of soil animal bodysize spectra at a global scale. We suggest that temperature influences soil community composition through temperature- and size-dependent metabolic demands, and soil $\mathrm{pH}$ and SOC reflect the availability of multiple nutrients that drive resource availability for different soil animal groups. Greater resolution global datasets of soil animal communities are needed to uncover the mechanisms underpinning environmental controls on soil communities. Such knowledge is needed to develop predictive soil ecology models capable of forecasting the effects of environmental changes on soil communities and ecosystem functions.

Acknowledgements This research has been financially supported by a NERC Soil Security Programme fellowship (NE/N019504/1). The authors would like to thank the editor and two anonymous reviewers for helpful suggestions which greatly improved the manuscript.

Author contribution statement AJ conceived the study idea, compiled and analysed the data. AJ and RS developed the statistical analysis. AJ led the writing of the manuscript and RS contributed to manuscript revisions.

Data accessibility The dataset compiled and analysed in this study is available from Dryad (https://doi.org/10.5061/dryad.6djh9w0xs).

Open Access This article is licensed under a Creative Commons Attribution 4.0 International License, which permits use, sharing, adaptation, distribution and reproduction in any medium or format, as long as you give appropriate credit to the original author(s) and the source, provide a link to the Creative Commons licence, and indicate if changes were made. The images or other third party material in this article are included in the article's Creative Commons licence, unless indicated otherwise in a credit line to the material. If material is not included in the article's Creative Commons licence and your intended use is not permitted by statutory regulation or exceeds the permitted use, you will need to obtain permission directly from the copyright holder. To view a copy of this licence, visit http://creativecommons.org/licenses/by/4.0/.

\section{References}

Aerts R (2006) The freezer defrosting: global warming and litter decomposition rates in cold biomes. J Ecol 94:713-724

Anderson J, Proctor J, Vallack H (1983) Ecological studies in four contrasting lowland rain forests in Gunung Mulu National Park, Sarawak: III. Decomposition processes and nutrient losses from leaf litter. J Ecol 71:503-527

Axelsson B, Lohm U, Persson T (1984) Enchytraeids, lumbricids and soil arthropods in a northern deciduous woodland-a quantitative study. Ecography 7:91-103 
Binkley D, Vitousek P (1989) Soil nutrient availability. In: Pearcy RW, Ehleringer JR, Mooney HA, Rundel PW (eds) Plant physiological ecology: field methods and instrumentation. Springer, Netherlands, pp 75-96

Blankinship JC, Niklaus PA, Hungate BA (2011) A meta-analysis of responses of soil biota to global change. Oecologia 165:553-565

Bokhorst S, Phoenix GK, Bjerke JW, Callaghan TV, Huyer-Brugman F, Berg MP (2012) Extreme winter warming events more negatively impact small rather than large soil fauna: shift in community composition explained by traits not taxa. Glob Change Biol 18:1152-1162

Bradford MA, Jones TH, Bardgett RD, Black HIJ, Boag B, Bonkowski M, Cook R, Eggers T, Gange AC, Grayston SJ, Kandeler E, McCaig AE, Newington JE, Prosser JI, Setälä H, Staddon PL, Tordoff GM, Tscherko D, Lawton JH (2002) Impacts of soil faunal community composition on model grassland ecosystems. Science 298:615-618

Briones MJI (2014) Soil fauna and soil functions: a jigsaw puzzle. Front Environ Sci 2:7

Briones MJI, Ostle NJ, McNamara NP, Poskitt J (2009) Functional shifts of grassland soil communities in response to soil warming. Soil Biol Biochem 41:315-322

Byzova JB, Uvarov AV, Petrova AD (1995) Seasonal changes in communities of soil invertebrates in tundra ecosystems of Hornsund, Spitsbergen. Polish Polar Res 16:245-266

Carrillo Y, Ball BA, Molina M (2016) Stoichiometric linkages between plant litter, trophic interactions and nitrogen mineralization across the litter-soil interface. Soil Biol Biochem 92:102-110

R Core Team (2018) R: a language and environment for statistical computing. R Foundation for Statistical Computing, Vienna, Austria. Available online at https://www.R-project.org/

Coulson J, Whittaker J (1978) Ecology of moorland animals. In: Heal OW, Perkins DF (eds) Production ecology of British moors and montane grasslands. Springer, Berlin, pp 52-93

De Deyn GB, Raaijmakers CE, Zoomer HR, Berg MP, de Ruiter PC, Verhoef HA, Bezemer TM, van der Putten WH (2003) Soil invertebrate fauna enhances grassland succession and diversity. Nature 422:711-713

Delgado-Baquerizo M, Reich PB, Khachane AN, Campbell CD, Thomas N, Freitag TE, Abu Al-Soud W, Sørensen S, Bardgett RD, Singh BK (2017) It is elemental: soil nutrient stoichiometry drives bacterial diversity. Environ Microbiol 19:1176-1188

Dell AI, Pawar S, Savage VM (2011) Systematic variation in the temperature dependence of physiological and ecological traits. Proc Natl Acad Sci 108:10591-10596

de Vries FT, Manning P, Tallowin JR, Mortimer SR, Pilgrim ES, Harrison KA, Hobbs PJ, Quirk H, Shipley B, Cornelissen JH (2012) Abiotic drivers and plant traits explain landscape-scale patterns in soil microbial communities. Ecol Lett 15:1230-1239

Dial RJ, Ellwood MDF, Turner EC, Foster WA (2006) Arthropod abundance, canopy structure, and microclimate in a Bornean lowland tropical rain forest. Biotropica 38:643-652

Dorrepaal JR, Kardol E, Nilsson M-CP, Teuber LM, Wardl DA (2016) Contrasting responses of soil microbial and nematode communities to warming and plant functional group removal across a postfire boreal forest successional gradient. Ecosystems 19:339-355

Eisenhauer N, Cesarz S, Koller R, Worm K, Reich PB (2012a) Global change belowground: impacts of elevated $\mathrm{CO}_{2}$, nitrogen, and summer drought on soil food webs and biodiversity. Glob Change Biol 18:435-447

Eisenhauer N, Reich PB, Isbell F (2012b) Decomposer diversity and identity influence plant diversity effects on ecosystem functioning. Ecology 93:2227-2240

Eisenhauer N, Stefanski A, Fisichelli NA, Rice K, Rich R, Reich PB (2014) Warming shifts 'worming': effects of experimental warming on invasive earthworms in northern North America. Sci Rep 4:6890

Ernakovich JG, Hopping KA, Berdanier AB, Simpson RT, Kachergis EJ, Steltzer H, Wallenstein MD (2014) Predicted responses of arctic and alpine ecosystems to altered seasonality under climate change. Glob Change Biol 20:3256-3269

Fierer N, Jackson RB (2006) The diversity and biogeography of soil bacterial communities. Proc Natl Acad Sci USA 103:626-631

Fierer N, Strickland MS, Liptzin D, Bradford MA, Cleveland CC (2009) Global patterns in belowground communities. Ecol Lett 12:1238-1249

García-Palacios P, Maestre FT, Kattge J, Wall DH (2013) Climate and litter quality differently modulate the effects of soil fauna on litter decomposition across biomes. Ecol Lett 16:1045-1053

Gill AL, Finzi AC (2016) Belowground carbon flux links biogeochemical cycles and resource-use efficiency at the global scale. Ecol Lett 19:1419-1428

Hadley NF (1982) Cuticle ultrastructure with respect to the lipid waterproofing barrier. J Exp Zool 222:239-248

Handa IT, Aerts R, Berendse F, Berg MP, Bruder A, Butenschoen O, Chauvet E, Gessner MO, Jabiol J, Makkonen M (2014) Consequences of biodiversity loss for litter decomposition across biomes. Nature 509:218

Hoste-Danyłow A, Ilieva-Makulec K, Olejniczak I, Hajdamowicz I, Stańska M, Marczak D, Wytwer J, Faleńczyk-Koziróg K, Ulrich W (2013) The shape of the intraspecific metabolic-rate-body-size relationship affects interspecific biomass and abundance distributions of soil animals within a forest ecosystem. Ann Zool Fenn 50:289-302

Huhta V, Koskenniemi A (1975) Numbers, biomass and community respiration of soil invertebrates in spruce forests at two latitudes in Finland. Ann Zool Fenn 12:164-182

Johnston AS (2019) Land management modulates the environmental controls on global earthworm communities. Glob Ecol Biogeogr 28:1787-1795

Johnston ASA, Sibly RM (2018) The influence of soil communities on the temperature sensitivity of soil respiration. Nat Ecol Evol 2:1597-1602

Koyama A, Wallenstein MD, Simpson RT, Moore JC (2014) Soil bacterial community composition altered by increased nutrient availability in Arctic tundra soils. Front Microbiol 5:516

Loranger G, Bandyopadhyaya I, Razaka B, Ponge J-F (2001) Does soil acidity explain altitudinal sequences in collembolan communities? Soil Biol Biochem 33:381-393

Lyth M (1982) Water-content of slugs (Gastropoda:Pulmonata) maintained in standardised culture conditions. J Molluscan Stud 48:214-218

Mack MC, Schuur EAG, Bret-Harte MS, Shaver GR, Chapin Iii FS (2004) Ecosystem carbon storage in arctic tundra reduced by longterm nutrient fertilization. Nature 431:440-443

Moulder BC, Reichle DE (1972) Significance of spider predation in the energy dynamics of forest-floor arthropod communities. Ecol Monogr 42:473-498

Mueller KE, Eisenhauer N, Reich PB, Hobbie SE, Chadwick OA, Chorover J, Oleksyn J (2016) Light, earthworms, and soil resources as predictors of diversity of 10 soil invertebrate groups across monocultures of 14 tree species. Soil Biol Biochem 92:184-198

Mulder C, Elser JJ (2009) Soil acidity, ecological stoichiometry and allometric scaling in grassland food webs. Glob Change Biol 15:2730-2738

Neff JC, Townsend AR, Gleixner G, Lehman SJ, Turnbull J, Bowman WD (2002) Variable effects of nitrogen additions on the stability and turnover of soil carbon. Nature 419:915-917

Parton W, Silver WL, Burke IC, Grassens L, Harmon ME, Currie WS, King JY, Adair EC, Brandt LA, Hart SC, Fasth B (2007) 
Global-scale similarities in nitrogen release patterns during longterm decomposition. Science 315:361-364

Persson T, Bååth E, Clarholm M, Lundkvist H, Söderström BE, Sohlenius B (1980) Trophic structure, biomass dynamics and carbon metabolism of soil organisms in a scots pine forest. Ecol Bull $32: 419-459$

Peters RH (1983) The ecological implications of body size. Cambridge University Press, Cambridge

Petersen H, Luxton M (1982) A comparative analysis of soil fauna populations and their role in decomposition processes. Oikos 39:288-388

Phillips HRP, Guerra CA, Bartz MLC, Briones MJI, Brown G, Crowther TW, Eisenhauer N (2019) Global distribution of earthworm diversity. Science 366:480-485

Redford KH, Dorea JG (1984) The nutritional value of invertebrates with emphasis on ants and termites as food for mammals. J Zool 203:385-395

Reich PB, Oleksyn J, Modrzynski J, Mrozinski P, Hobbie SE, Eissenstat DM, Chorover J, Chadwick OA, Hale CM, Tjoelker MG (2005) Linking litter calcium, earthworms and soil properties: a common garden test with 14 tree species. Ecol Lett 8:811-818

Richardson BA, Richardson MJ, Soto-Adames FN (2005) Separating the effects of forest type and elevation on the diversity of litter invertebrate communities in a humid tropical forest in Puerto Rico. J Anim Ecol 74:926-936

Robinson SI, McLaughlin OB, Marteinsdóttir B, O’Gorman EJ (2018) Soil temperature effects on the structure and diversity of plant and invertebrate communities in a natural warming experiment. $\mathrm{J}$ Anim Ecol 87:634-646

Rosswall T, Persson T, Lohm U (1977) Energetical significance of the annelids and arthropods in a Swedish grassland soil. Ecol Bull 23:1-211

Rousk J, Bååth E, Brookes PC, Lauber CL, Lozupone C, Caporaso JG, Knight R, Fierer N (2010) Soil bacterial and fungal communities across a pH gradient in an arable soil. ISME J 4:1340-1351

Sage RD (1982) Wet and dry-weight estimates of insects and spiders based on length. Am Midl Nat 108:407-411

Schlaghamerský J, Devetter M, Háněl L, Tajovský K, Starý J, Tuf IH, Pižl V (2014) Soil fauna across Central European sandstone ravines with temperature inversion: from cool and shady to dry and hot places. Appl Soil Ecol 83:30-38

Serna-Chavez HM, Fierer N, Bodegom PM (2013) Global drivers and patterns of microbial abundance in soil. Glob Ecol Biogeogr 22:1162-1172

Sinsabaugh RL, Lauber CL, Weintraub MN, Ahmed B, Allison SD, Crenshaw C, Contosta AR, Cusack D, Frey S, Gallo ME (2008) Stoichiometry of soil enzyme activity at global scale. Ecol Lett 11:1252-1264

Sjursen H, Michelsen A, Jonasson S (2005) Effects of long-term soil warming and fertilisation on microarthropod abundances in three sub-arctic ecosystems. Appl Soil Ecol 30:148-161

Suttle KB, Thomsen MA, Power ME (2007) Species interactions reverse grassland responses to changing climate. Science 315:640-642

Swift M, Andren O, Brussaard L, Briones M, Couteaux MM, Ekschmitt K, Kjoller A, Loiseau P, Smith P (1998) Global change, soil biodiversity, and nitrogen cycling in terrestrial ecosystems: three case studies. Glob Change Biol 4:729-743
Tedersoo L, Bahram M, Põlme S, Kõljalg U, Yorou NS, Wijesundera R, Ruiz LV, Vasco-Palacios AM, Thu PQ, Suija A, Smith ME, Sharp C, Saluveer E, Saitta A, Rosas M, Riit T, Ratkowsky D, Pritsch K, Põldmaa K, Piepenbring M, Phosri C, Peterson M, Parts K, Pärtel K, Otsing E, Nouhra E, Njouonkou AL, Nilsson RH, Morgado LN, Mayor J, May TW, Majuakim L, Lodge DJ, Lee SS, Larsson K-H, Kohout P, Hosaka K, Hiiesalu I, Henkel TW, Harend H, Guo L-D, Greslebin A, Grelet G, Geml J, Gates G, Dunstan W, Dunk C, Drenkhan R, Dearnaley J, De Kesel A, Dang T, Chen X, Buegger F, Brearley FQ, Bonito G, Anslan S, Abell S, Abarenkov K (2014) Global diversity and geography of soil fungi. Science 346:1256688

Thakur MP, Reich PB, Fisichelli NA, Stefanski A, Cesarz S, Dobies T, Rich RL, Hobbie SE, Eisenhauer N (2014) Nematode community shifts in response to experimental warming and canopy conditions are associated with plant community changes in the temperateboreal forest ecotone. Oecologia 175:713-723

Törmälä T (1979) Numbers and biomass of soil invertebrates in a reserved field in central Finland. Agric Food Sci 51:172-187

Treseder KK (2008) Nitrogen additions and microbial biomass: a metaanalysis of ecosystem studies. Ecol Lett 11:1111-1120

Van Den Hoogen J, Geisen S, Routh D, Ferris H, Traunspurger W, Wardle DA, Andriuzzi WS (2019) Soil nematode abundance and functional group composition at a global scale. Nature 572:194-198

Van der Wal A, Geerts R, Korevaar H, Schouten AJ, Akkerhuis GJ, Rutgers M, Mulder C (2009) Dissimilar response of plant and soil biota communities to long-term nutrient addition in grasslands. Biol Fertil Soils 45:663-667

Wagg C, Bender SF, Widmer F, van der Heijden MG (2014) Soil biodiversity and soil community composition determine ecosystem multifunctionality. Proc Natl Acad Sci 111:5266-5270

Wall DH, Bradford MA, St John MG, Trofymow JA, Behan-Pelletier V, Bignell DE, Dangerfield JM, Parton WJ, Rusek J, Voigt W, Wolters V, Gardel HZ, Ayuke FO, Bashford R, Beljakova OI, Bohlen PJ, Brauman A, Flemming S, Henschel JR, Johnson DL, Jones TH, Kovarova M, Kranabetter JM, Kutny LES, Lin K-C, Maryati M, Masse D, Pokarzhevskii A, Rahman H, SabarÁ MG, Salamon J-A, Swift MJ, Varela A, Vasconcelos HL, White DON, Zou X (2008) Global decomposition experiment shows soil animal impacts on decomposition are climate-dependent. Glob Change Biol 14:2661-2677

Wardle DA (2002) Communities and ecosystems: linking the aboveground and belowground components. Princeton University Press, Princeton

Wardle DA (2006) The influence of biotic interactions on soil biodiversity. Ecol Lett 9:870-886

Wardle DA, Bardgett RD, Klironomos JN, Setälä H, van der Putten WH, Wall DH (2004) Ecological linkages between aboveground and belowground biota. Science 304:1629-1633

Xu G, Lin Y, Zhang S, Zhang Y, Li G, Ma K (2017) Shifting mechanisms of elevational diversity and biomass patterns in soil invertebrates at treeline. Soil Biol Biochem 113:80-88

Yang G, Wagg C, Veresoglou SD, Hempel S, Rillig MC (2018) How soil biota drive ecosystem stability. Trends Plant Sci 23:1057-1067 